\title{
DESERDAÇÃO: \\ LEGÍTIMA E AUTONOMIA DO TESTADOR
}

\section{Cristiano Pretto $^{1}$}

\section{INTRODUÇÃO}

O texto a seguir revisita antigo instituto do Direito das Sucessões: a deserdação, ato pelo qual o testador priva o herdeiro necessário de sua legítima, excluindo-o da sucessão.

Conforme art. 1.961, do Código Civil brasileiro: "os herdeiros necessários podem ser privados de sua legítima, ou deserdados, em todos os casos em que podem ser excluídos da sucessão”.

Para tanto, algumas premissas introdutórias são necessárias.

Primeiro, diga-se que o Direito das Sucessões trata exclusivamente da sucessão causa mortis, que pode ocorrer conforme disciplina a lei (su- cessão legítima) ou por vontade do titular dos direitos (sucessão testamentária). “A sucessão à causa de morte é toda a sucessão em que há o prefalecido e o sobrevivente, ou os sobreviventes, que recolhem a herança, senso lato, isto é, os herdeiros, os legatários e outros beneficiados". ${ }^{2}$ Evidentemente, há sucessão entre vivos, fenômeno do qual não se ocupa este texto. A deserdação aparece quando do tratamento da sucessão testamentária, pois deve ser instituída por testamento, mas tal característica "não lhe apaga a ligação à sucessão legítima, tanto mais quanto o seu fim é suprimir a necessariedade, portanto, também a legitimidade da vocação". ${ }^{3}$

1 Advogado. Mestre em Direito pela Universidade Federal do Rio Grande do Sul.

2 PONTES DE MIRANDA. Tratado de direito privado. Parte Especial. Tomo LV. Direito das Sucessões: Sucessão em Geral. Sucessão Legítima. 3. ed. Rio de Janeiro: Borsoi, 1972, p. 5.

3 Idem, p. 296. 
Ressalvados os manuais de Direito das Sucessões e as obras clássicas, ainda hoje se verifica certa negligência da doutrina nacional quanto ao tratamento de temas específicos ao Direito das Sucessões. ${ }^{4}$
Um exemplo é a deserdação. ${ }^{5} \mathrm{~A}$ escassez de material doutrinário específico e a existência de debate nos Tribunais ${ }^{6}$ emergem como razão do estudo.

Para tratar sobre o assunto, a primeira parte do texto traz breve notícia

4 No Brasil, tem-se as obras clássicas de nomes como Clóvis Beviláqua (Direito das sucessões. Ed. José Luiz da Fonseca Magalhães, Salvador, 1899), Pontes de Miranda (Tratado de direito privado. 3. ed. São Paulo: Revista dos Tribunais, 1984, Tomos 55 a 60); Carlos Maximiliano (Direito das sucessões. Rio de Janeiro: Freitas Bastos, 1964); Itabaina de Oliveira (Tratado de direito das sucessões. São Paulo: Max Limonad, 1952); e Carvalho Santos (Código Civil Brasileiro de 1916 interpretado. v. XXII. Rio de Janeiro: Freitas Bastos, 1937).

Depois, nossos tratadistas mais modernos e seus manuais de Direito Civil, notadamente Orlando Gomes (Sucessões. Rio de Janeiro: Forense, 1998) e Caio Mário da Silva Pereira (Instituições de direito civil. v. 6. 11. ed. Rio de Janeiro: Forense, 1996).

Recentemente, os estudos de Zeno Veloso (Comentários ao novo Código Civil, v. 21. São Paulo: Saraiva, 2002) e a obra de Francisco José Cahali e Giselda Maria Novaes Hironaka (Direito das sucessões. 3. ed. São Paulo: Revista dos Tribunais, 2007).

$5 \mathrm{Na}$ doutrina nacional, uma das poucas obras de maior fôlego sobre o tema é o estudo de CATEB, Salomão de Araújo. Deserdação e indignidade no direito sucessório brasileiro. Belo Horizonte: Del Rey, 2004.

6 Recentes julgamentos no Superior Tribunal de Justiça trataram sobre o instituto: BRASIL. Superior Tribunal de Justiça. Recurso Especial n. 124.313-SP, 4 $4^{\mathrm{a}}$ Turma. Recorrente: M. T. B. B. Recorrido: O. R. B. S. Relator: Ministro Luis Felipe Salomão. Brasília, 16 de abril de 2009; BRASIL. Superior Tribunal de Justiça. Recurso Especial n. 1185122-RJ, Relator: Ministro Massami Uyeda. DJe 02/03/2011. Disponíveis em: $<$ http://www.stj.jus.br>.

No Tribunal de Justiça podem ser citados: RIO GRANDE DO SUL. Tribunal de Justiça. Apelação cível n. 70029040417, da $8^{a}$ Câmara Cível. Apelante: S. G. C. Apelado: N. C. T. Relator: Claudir Fidelis Faccenda. Porto Alegre, 21 de maio de 2009. RIO GRANDE DO SUL. Tribunal de Justiça. Apelação cível n. 70007827397, da $7^{\text {a }}$ Câmara Cível. Apelante: E. F. R. e M. S. V. R. Apelado: N. F. R. Relator: Maria Berenice Dias. Porto Alegre, 05 de maio de 2004. RIO GRANDE DO SUL. Tribunal de Justiça. Apelação cível n. 70002568863, da $8^{\text {a }}$ Câmara Cível. Apelante: S. F. V. Apelado: S. I. P. Relator: José Ataídes Siqueira Trindade. Porto Alegre, 31 de maio de 2001. RIO GRANDE DO SUL. Tribunal de Justiça. Apelação cível n. 591021944, da $7^{a}$ Câmara Cível. Apelante: M. J. D. Apelado: S. I. P. Relator: Waldemar Luiz de Freitas Filho. Porto Alegre, 16 de outubro de 1991. RIO GRANDE DO SUL. Tribunal de Justiça. Apelação cível n. 585030133, da $5^{\text {a }}$ Câmara Cível. Apelante: A. A. R. Apelado: W. H. R. Relator: Ruy Rosado de Aguiar Júnior. Porto Alegre, 03 de junho de 1986. Acórdãos disponíveis em 
histórica do instituto para alcançar as regras previstas no Código Civil de 2002. Ainda na primeira parte, oferece-se o debate acerca das ligações entre o instituto da deserdação e a autonomia privada.

Na segunda parte do trabalho, com base nas assertivas iniciais, escreve-se acerca do fundamento da deserdação, superando seu paradigma patrimonial e individualista, para, ao final, dissertar sobre a concretização do perdão e os efeitos da deserdação.

Alerta-se, como última nota introdutória, que o texto não desenvolve as semelhanças e/ou diferenças entre deserdação e indignidade, que é outra forma de exclusão da herança, de qualquer herdeiro e/ou legatário, a ser declarada por sentença (art. 1.814 e 1.815, do Código Civil). ${ }^{7}$

\section{DESERDAÇÃO NA EXPERIÊNCIA JURÍDICA}

Considera-se importante a revisão histórica dos institutos para evitar o anacronismo. Além disso, deve-se considerar que o "direito vigente", dá-se “em função de valorações prevalecentes em dado meio social e histórico". ${ }^{8}$

Por essa razão, o texto comporta breve notícia histórica, a fim de apresentar os parâmetros do instituto ao longo do tempo (A). Além disso, tendo em vista que o instituto da legítima (da reserva legal) é talvez o maior limite da vontade do "autor da herança” e a deserdação acaba impedindo a aplicação da regra de reserva, parece importante traçar linhas gerais entre

<http://.www.tjrs.jus.br>. Acesso em: 09 jul. 2009.

Mais antigos são os julgamentos no Supremo Tribunal Federal: BRASIL. Supremo Tribunal Federal. Recurso Extraordinário n. 16.845, $1^{\text {a }}$ Turma. Recorrente: M. B. L. F. Recorrido: P. B. L. Relator: Ministro Luis Gallotti. Brasília, 10 de julho de 1950. BRASIL. Supremo Tribunal Federal. Recurso Extraordinário n. 65.550, $1^{\mathrm{a}}$ Turma. Recorrente: M. J. A. Recorrido: J. L. Relator: Ministro Amaral Santos. Brasília, 30 de setembro de 1969. Acórdãos disponíveis em: <http://www.stf.jus.br>.

7 Ilustrativamente, veja-se interessante quadro que aponta as diferenças entre deserdação e indignidade na obra de HIRONAKA, Giselda Maria Novaes. Direito das sucessões. 3. ed. São Paulo: Revista dos Tribunais, 2007, p. 300.

8 REALE. Miguel. $O$ direito como experiência. 2. ed. São Paulo: Saraiva, 2002, p. 201-202. 
estes conceitos: autonomia privada, legítima e deserdação (B).

É o que se faz a seguir.

\section{A) Do Direito Romano à experiência brasileira}

Spencer Vampré afirmava que historicamente o homem preocupa-se com a sucessão por causa da morte: "nada interessa tanto ao homem, depois de satisfeitas as necessidades materiais, do que o futuro de sua descendência". ${ }^{9}$

Em que pese se encontrar notícias sobre deserdação em períodos ainda mais remotos ${ }^{10}$, tem-se como menos controversa sua origem no Direito Romano, período intermédio, constando os motivos que a autorizavam na famosa Novela 115, de Justiniano.

No entanto, primeiro "herdeiro é o filho, o suus. Tudo mais vem depois, inclusive o testamento. Talvez a deserdação seja anterior a esse, era preciso deserdar, para que o testamento pudesse existir. No começo, o automatismo do filho que sucede o pai no culto e no poder. Deserdado o suus, vem, após, a instituição". ${ }^{11}$

Depois, "para a deserdação, bastava que o pai a tivesse querido, mesmo quando o direito romano protegeu, somente com caráter formal, os sui heredes. Antes havia a liberdade de testar ilimitada. A deserdação havia de ser expressa. Não se precisava de causa ou fundamento para o ato deserdativo". ${ }^{12}$

Ainda a título de esboço histórico, ultrapassada a origem romana do instituto, verifica-se que as legislações dos povos cultos não são acordes sobre a deserdação.

Algumas, como a francesa, tratam somente dos casos de indignidade na sucessão legítima, não se preocupando com a deserdação; outras, como a italiana, tratam dos casos de indigni-

9 VAMPRÉ, Spencer. O que é o Código Civil. Conferências. São Paulo: Magalhães, s/d., p. 121.

10 Incontroverso que os romanos receberam-na das civilizações orientais mais antigas, havendo quem encontre suas raízes longínquas no Código de Hamurabi (VELOSO, Zeno. Testamentos de acordo com a Constituição de 1988. 2. ed. Belém: CEJUP, 1993, p. 447).

11 PONTES DE MIRANDA. Tratado de direito privado. Parte Especial. Tomo LVIII. Direito das Sucessões: Sucessão Testamentária. Disposições testamentárias em geral, Formas ordinárias do testamento. 2. ed. Rio de Janeiro: Borsoi, 1969, p. 247.

12 PONTES DE MIRANDA. Tratado de direito privado. Parte Especial. Tomo LV. Direito das Sucessões: Sucessão em Geral. Sucessão Legítima. 3. ed. Rio de Janeiro: Borsoi, 1972, p. 295. 
dade na sucessão legítima e os estendem à sucessão testamentária; outras, como a alemã, apresentam uma teoria de indignidade aplicável às três espécies de devolução: a legítima, a testamentária e a contratual; ${ }^{13}$ outras, finalmente, como a suíça, a espanhola, a argentina e a brasileira, tratam tantos dos casos de indignidade na sucessão legítima como dos de deserdação, na sucessão testamentária. ${ }^{14}$

No Brasil, Beviláqua não previu o instituto no Projeto primitivo, considerando instituto odioso e inútil (com o que, regra geral, a doutrina nacional concordava). No entanto, o Código Civil de 1916 fez previsões acerca da deserdação, mantendo a tradição do instituto.

O Código Civil de 2002 manteve as regras sobre deserdação (artigos 1.961 até 1.965$)$.
Comentando as regras do Código Civil de 2002, Zeno Veloso afirma que "decotadas algumas causas ultrapassadas e anacrônicas, e parificados os seus efeitos com os da exclusão por indignidade, a deserdação é um instituto que pode apresentar serventia e préstimo, devendo permanecer em nosso Código". ${ }^{15}$

Nota-se que as legislações dos povos civilizados vêm mantendo o instituto da deserdação, de eminente caráter patrimonial (exclusão quanto aos bens da herança), fundamentado em atos reprováveis do herdeiro contra o autor da herança, capazes de remover todos os entraves de ordem pública que o legislador impôs à vontade do testador, devolvendo-lhe a sua plenitude.

Poder-se-ia dizer mesmo que o instituto visa concretizar a eticidade ${ }^{16}$ no que se refere ao direito da legítima, pois se a obrigação de transmis-

13 Vale informar que no início de 2010 entrou em vigor na Alemanha legislação que alterou algumas regras de Direito das Sucessões, as quais afetaram de forma mais intensa a regulação da legítima e as causas de deserdação. Sobre a deserdação, a principal alteração foi ampliar as pessoas que podem ser atingidas pelos atos que fundamentam a deserdação do herdeiro (atos contra autor da herança, cônjuge, descendentes e "outras pessoas próximas ao autor da herança - §2.333, do BGB", bem como unificar as causas de privação, eliminando diferenças em razão de parentesco, além de indicar como causa de deserdação a condenação por delito com pena de, no mínimo, um ano, inaceitável para o autor da herança, sem identificar quais os delitos e afirmar que eles devem ser inaceitáveis ao autor da herança; por exemplo, um delito de racismo pode não ser inaceitável ao autor da herança, portanto, não determinará deserdação).

14 ITABAIANA DE OLIVEIRA, Arthur Vasco. Tratado de direito das sucessões. São Paulo: Max Limonad, 1952, p. 420.

15 VELOSO. 1993, op. cit., p. 448.

16 Eticidade, socialidade e operabilidade são os princípios basilares do Direito Privado brasileiro atual. Sobre o tema: REALE, Miguel. Visão geral do Projeto de Código 
são de parcela significativa dos bens deixados em herança aos herdeiros necessários tem como fundamento a solidariedade que deve existir entre pessoas que possuam determinado laço familiar, parece mesmo incompatível eticamente que algum ofensor do autor da herança ainda seja beneficiado posteriormente.

Verificadas as linhas históricas gerais sobre a deserdação, já é possível ingressar em tema que se entende de grande relevância ao assunto tratado: as relações entre autonomia privada e deserdação.

\section{B) Autonomia privada, legítima e deserdação}

Como visto acima, Roma conheceu a liberdade ilimitada de testar e, também, de deserdar, sem sequer a indicação da causa da deserdação.

Bem mais adiante, os Códigos modernos basearam-se nos paradigmas da revolução burguesa. Tanto o Código Civil francês quanto o Código Civil alemão, os dois principais Códigos burgueses, consagraram o individualismo (o homem como centro do mundo), o liberalismo (o homem tem direito a liberdade) e o voluntarismo (o homem pode se conduzir de acordo com a sua autonomia).

No entanto, em se tratando de Direito das Sucessões, ambos instituíram a reserva legal dos bens do de cujus para herdeiros ditos necessários. Ou seja, parte do patrimônio do autor da herança destinada por lei a alguns herdeiros (em especial descentes e ascendentes). ${ }^{17}$ Trata-se da legítima, talvez a maior limitação à liberdade

Civil. Revista dos Tribunais, n. 752, p. 22-30, 1998. [...] “em todo ordenamento jurídico há artigos-chave, isto é, normas fundantes que dão sentido às demais, sintetizando diretrizes válidas 'para todo o sistema'. [...] "nessa ordem de ideias, nenhum dos artigos do novo Código Civil me parece tão rico de consequência como o artigo 113, segundo o qual 'os negócios jurídicos devem ser interpretados conforme a boa-fé e os usos do lugar de sua celebração'. Note-se que esse dispositivo já figurava, sob n ${ }^{\circ} 112$, no Anteprojeto de 1972, antes, pois, de seu conhecimento pelo Congresso Nacional. Desdobrando essa norma em seus elementos constitutivos, verifica-se que ela consagra a eleição específica dos negócios jurídicos como disciplina preferida para regulação genérica das relações sociais, sendo fixadas, desde logo, a eticidade de sua hermenêutica, em função da boa-fé, bem como a sua socialidade, ao se fazer alusão aos 'usos do lugar de sua celebração’. Eis aí já esboçada a incidência dos três princípios (eticidade, socialidade e operabilidade) que, a meu ver, presidem à atual Lei Civil [...]” (REALE, Miguel. Um artigo-chave do Código Civil. In: Reale, Miguel. Estudos preliminares do Código Civil. São Paulo: Saraiva, 2003, p. 75).

17 Note-se que o Código Civil brasileiro elegeu o cônjuge como herdeiro necessário, ao lado dos ascendentes e descendentes. Este texto não abordará esse tema, mas aqui 
de testar, de dispor dos seus bens para depois da morte: limitação da autonomia privada do testador.

Verifica-se o que Ferri alertava: os interesses superiores ou públicos que se deseja proteger nessa sede são limites da autonomia privada, um limite negativo, ou seja, limitação a decisão autônoma. Em jogo de interesses superiores não há lugar para a autonomia privada. ${ }^{18}$

Mesmo com a limitação, o instituto da deserdação vem sendo mantido com o passar dos tempos e funciona como uma exceção à regra da reserva legal e exaltação da vontade do autor da herança.

Nesse contexto, em que medida o testador é livre para deserdar um de seus herdeiros necessários? Poderá deserdá-lo totalmente? Em caso de caducidade do legado, nulidade do testamento ou da nulidade da cláusula de deserdação, a vontade do testador não deveria ser preservada? E o perdão, só admite-se pelo mesmo meio (testamento)? Todas essas perguntas só podem ser respondidas quando se visualiza a autonomia privada como fonte do "direito de deserdar". ${ }^{19}$

Não há espaço neste texto para desenvolver todas as ligações entre autonomia privada e deserdação. Também não é possível descrever toda evolução da autonomia privada no Direito Civil moderno. No entanto, deve-se ter em mente que a autonomia privada permanece como papel importante no Direito Privado. Todavia, não é possível reduzir todas as consequências dos atos jurídicos à declaração de vontade dos envolvidos.

já uma nota crítica ao instituto, que parece ser mantido nos Códigos mais por tradição do que por utilidade. Para excluir o cônjuge da sucessão é necessário deserdá-lo? Caso um dos cônjuges cometa contra o outro algum ato ofensivo arrolado como causa de deserdação não bastaria o rompimento do vínculo conjugal para excluí-lo da sucessão? Evidente que o instituto da deserdação em relação ao cônjuge é de todo inútil. Interessante notar que os artigos 1.962 e 1.963 do Código Civil apresentam apenas as causas que autorizam a deserdação dos descendentes e dos ascendentes, silenciando-se quanto ao cônjuge. Isso, talvez, porque a deserdação não seja instituto hábil para a exclusão do cônjuge.

18 FERRI, Luigi. La Autonomia Privada. Trad. y notas por Luis Sancho Mendizabal. Madrid: Revista de Derecho Privado, 1969, p. 12-13. Sobre o princípio da autonomia privada, sua evolução e função fundamental na ordem jurídica, ver AMARAL, Francisco. A autonomia privada como princípio fundamental da ordem jurídica. Perspectivas estrutural e funcional. Boletim da Faculdade de Direito de Coimbra. Número Especial. Estudos em homenagem ao Prof. Doutor Ferrer-Correia. Coimbra: Coimbra, 1989.

19 BUFFELAN-LANORE, Yvaine. L'Autonomie de la Volonté em Matière D’Exhérédation. Revue Trimestrielle de Droit Civil, p. 456-480, LXIV, 1966. 
Atualmente, as ideias que se contrapõem numa sociedade de massas, os (novos) interesses em conflito, interferem na ordem da vida humana, alterando diretrizes, certezas e planos. O indivíduo já não pode ser visto de forma isolada, sob pena de ser transformado em peça auxiliar dos instrumentos que inventa. ${ }^{20}$

Ao lado da autonomia privada, a dogmática moderna admite a jurisdicização de certos interesses em cujo núcleo não se manifesta o aspecto volitivo. Com efeito, "em qualquer ordem jurídica há uma solução de compromisso entre os fins individuais e os fins sociais" ${ }^{21}$, e o ordenamento concilia esses limites quando permite uma zona lícita para exercício de um direito, fazendo-o ilegítimo quando excede, objetivamente, os limites impostos pelo fim social ou econômico desse direito.

Por isso, quando se estuda instituto cuja fonte é a vontade do agente, deve-se estar atento em especial aos princípios formadores do sistema jurídico privado moderno, mormente os princípios da boa-fé, da eticidade e da socialidade.
Por isso, "hoje a deserdação há de ser fundada. A deserdação passou a ser declaração de fato e vontade, de modo que não mais é manifestação de vontade vazia de causa: fez-se manifestação de vontade, com essencial elemento declarativo ('houve, ou há isso')". ${ }^{22}$

Mais do que isso, colocada a discussão nesses termos, o debate acerca da aceitação de causas de deserdação ou alargamento de hipóteses vem com outros pressupostos, tais como da eticidade e da socialidade.

A importância de partir desses pressupostos para o caso da deserdação pode ser exemplificada em razão da regra do art. 1.860, parágrafo único, do Código Civil, que refere que "podem testar os maiores de 16 (dezesseis anos)".

Portanto, considerando que o testamento é ato personalíssimo (art. 1.858, do Código Civil), a lei dá autonomia para a pessoa considerada relativamente incapaz pela legislação (art. $4^{\circ}$, I, do Código Civil). Nessa linha, o relativamente incapaz é pleno para decidir sobre deserdação de, por exemplo, seu ascendente. Evidente que

20 Sobre o tema: MARINHO, Josaphat. O direito e as contradições da lei e da vida. Revista de Informação Legislativa, ano 35, n. 138, Brasília, p. 49-54, abr./jun. 1998.

21 CAPELO DE SOUSA, Rabindranath Valentino Aleixo. O direito geral de personalidade. Coimbra: Coimbra, 1995, p. 520.

22 PONTES DE MIRANDA. Tratado de direito privado. Parte Especial. Tomo LV. Direito das Sucessões: Sucessão em geral. Sucessão legítima. 3. ed. Rio de Janeiro: Borsoi, 1972, p. 295. 
tais decisões, fundadas na autonomia do testador, devem ser avaliadas com base nos valores comentados acima.

Com base no panorama desenvolvido até aqui, conclui-se essa parte do texto afirmando que a legítima (art. 1.846 e 1.789 , do CC) é limitação da vontade do autor da herança e a deserdação atua como exceção a regra e exaltação da vontade (autonomia) do titular da herança.

Portanto, para discutir as regras sobre deserdação, deve-se partir do perfeito entendimento acerca da autonomia privada no direito moderno, em especial sob o crivo da boa-fé, da eticidade e da socialidade.

Com base nas diretrizes acima, parte-se para a segunda parte do trabalho, reduzindo a discussão acerca das relações entre autonomia privada e deserdação ao que se entende mais importante: o fundamento e a função da deserdação e a concretização do perdão e os efeitos da deserdação.

\section{DESERDAÇÃO NO DIREITO BRASILEIRO}

Identificada a origem e evolução histórica da deserdação e visto que todo debate deve partir do perfeito entendimento da autonomia do testador, já é possível ingressar especifica- mente sobre temas de deserdação no Direito brasileiro.

Com efeito, considerando os limites deste trabalho, a segunda parte do texto reduz a discussão ao fundamento e à função da deserdação (A) e, depois, ao perdão e aos efeitos da deserdação (B).

Explica-se: o fundamento da deserdação deve ser reavaliado. Sobre isso se discute no item A, infra. Reavaliado o fundamento, pode-se debater, com nova visão, sobre o perdão e sobre os efeitos da deserdação.

\section{A) Fundamento e função da deserdação}

Com sua clareza peculiar, ao comentar o instituto com base no Código Civil de 1916, Pontes de Miranda afirma:

qual o fundamento da deserdação? Não deveria ser uma pena; à alma contemporânea só serviria a alegação de não caber a sucessão necessária quando, com a morte do decujo, o herdeiro não precisa, é um desligado da família, de que não deve receber proveitos. Mas a verdade é que o Código Civil manteve o caráter odioso de pena, reflexo assaz compreensível do individualismo estacionário do direito das sucessões. ${ }^{23}$

23 PONTES DE MIRANDA. Tratado de direito privado. Parte Especial. Tomo LVIII. Direito das Sucessões: Sucessão testamentária. Disposições testamentárias em geral, Formas ordinárias do testamento. 2. ed. Rio de Janeiro: Borsoi, 1969, p. 248. 
Visualizado o instituto sobre as regras do Código Civil de 2002, não parece possível desmentir a percepção de Pontes de Miranda: o fundamento da deserdação permanece como pena, em especial porque a regra do novo Código é praticamente idêntica ao do Código de 1916.

Mas o fundamento da família (e a deserdação atinge especialmente as relações familiares) no Direito atual permanece o mesmo?

A família que se protege atualmente, bem diferente da ideia do individualismo, é a “família igualitária-integrativa, na qual se verifica uma crescente personalização de todos os seus membros, criando-se direitos e deveres para o ente comunitário e para cada um dos seus membros em particular”. ${ }^{24}$ Trata-se da família que cuida do desenvolvimento pessoal de cada um no ambiente familiar e na sociedade, da convivência respeitosa e da assistência recíproca.

Essa transformação social ocorreu por vários fatores, como, por exemplo, o processo de urbanização e a industrialização ocorrida no país, de forma a não ser imprescindível uma família extensa, pelo contrário, o núcleo familiar importava em ser pequeno para facilitar a vida na cidade; o ingresso da mulher no mercado de trabalho e o aumento da sua atuação social, política e jurídica; bem como a transformação da condição social do jovem. ${ }^{25}$

O termo "família", hoje, tem significado plural, ou seja, entidades familiares constituídas através do casamento, da união estável, entidades

Como visto na Parte I, item A, supra, o Direito das Sucessões funda-se largamente no direito romano (clássico e pós-clássico), em que predominava a sucessão testamentária, de caráter individualista, mas também é influenciado pelo direito germânico, de espírito comunitário, inteiramente oposto à autonomia da vontade. Durante a Idade Média, acrescentou-se, a ambas camadas, o direito canônico. Este, de resto, pela própria índole, já mantinha, em si mesmo, frágil equilíbrio entre as exigências religiosas de proteção à pessoa humana (e, portanto, exigências individualistas) e à família (o que vem a dar em posições supraindividualistas). Sobre o tema: AZEVEDO, Antônio Junqueira de. O espírito de compromisso do Direito das Sucessões perante as exigências individualistas de autonomia da vontade e as supraindividualistas da família - herdeiro e legatário. Revista Brasileira de Direito de Família, n. 4, p. 56, jan./fev./mar. 2000.

24 NORONHA, Carlos Silveira. Conceito e fundamentos de família e sua evolução na ordem jurídica. Revista Forense, v. 326, 1994, p. 28.

25 CARBONERA, Silvana Maria. O papel jurídico do afeto nas relações de família. In: FACHIN, Luiz Edson (Coord.). Repensando fundamentos do Direito Civil contemporâneo. Rio de Janeiro: Renovar, 1998, p. 284. 
monoparentais, uniões homossexuais ${ }^{26}$, entendimento encontrado nos principais ordenamentos jurídicos do ocidente. $^{27}$
Além disso, no que se refere à normatização do Direito de Família propriamente dito, o Código Civil de 2002 contém importantíssimo avanço,

26 "O desenho familiar não tem mais uma única configuração. A família se torna plural. Da superação do antigo modelo da grande-família, na qual avultava o caráter patriarcal e hierarquizado da família, uma unidade centrada no casamento, nasce a família constitucional, com a progressiva eliminação da hierarquia, emergindo uma restrita liberdade de escolha [...]. Na família constitucionalizada começam a dominar as relações de afeto, de solidariedade e de cooperação. Proclama-se, com mais acento, a concepção eudemonista da família: não é mais o indivíduo que existe para a família e para o casamento, mas a família e o casamento existem para o seu desenvolvimento pessoal, em busca de sua aspiração à felicidade” (FACHIN, Luiz Edson. Desafios e perspectivas do Direito de Família no Brasil contemporâneo. In: AZEVEDO; TÔRRES; CARBONE (Coord.). Princípios do novo Código Civil Brasileiro e outros temas. Homenagem a Tullio Ascarelli. São Paulo: Quartier Latin, 2008, p. 437-438). Um exemplo é o julgamento do Supremo Tribunal Federal que resultou no entendimento de que a união homossexual, ao lado do casamento, da união estável, da monoparentalidade, é entidade familiar (ADI n. 4277 e a ADPF n. 132, Tribunal Pleno, Rel. Min. Ayres Brito, j. em 05.05.2011). De forma muito sintética, pode-se dizer que decidiu o Pleno do Supremo Tribunal Federal, acompanhando o entendimento do relator, que o artigo 1.723 do Código Civil não impede o reconhecimento da união entre pessoas do mesmo sexo como entidade familiar, além das outras entidades familiares já consagradas no ordenamento. Segundo o voto do Ministro Ayres Britto: [...] "dou ao art. 1.723 do Código Civil interpretação conforme a Constituição para dele excluir qualquer significado que impeça o reconhecimento da união contínua, pública e duradoura entre pessoas do mesmo sexo como 'entidade familiar', entendida esta como sinônimo perfeito de 'família'.

27 A significação plural da expressão "família", ou, de outra forma, a ausência de um conceito fechado de família é bem explicada pela doutrina alemã. Segundo Wilfried Schluter, "uma ampla normatização iria destruir as bases pessoais da família, a disposição para a solidariedade espontânea, e com isto mesmo dissolvê-la. O legislador deixou por isto, com bom motivo, a regulamentação da vida conjunta familiar, preponderantemente a cargo da autonomia da família. Tarefa da ordem jurídica somente pode ser, criar, em esboço, as condições gerais, 'um perfil normativo condizente' com a família como instituição social e garantir a proteção jurídica em todos os casos, nos quais conflitos familiares não possam (mais) ser regulados autonomamente, ou porque a sociedade conjugal está falida ou porque os pais menosprezam suas obrigações para com os filhos" (SCHLUTER, Wilfried. Código Civil Alemão - Direito de Família. Trad. da $9^{a}$ ed. por Elisete Antoniuk. Porto Alegre: Fabris, 2002, p. 57). Na Alemanha, o Código Civil protege a sociedade conjugal constituída pelo casamento, mas a jurisprudência reconhece a união estável entre pessoas não impedidas de casar. Ainda, a Lei da União Estável de 22.02.2001 terminou com a discriminação das uniões homossexuais (tudo melhor explicado na mesma obra de Schluter, citada acima). 
que é de "separar os institutos segundo relações jurídicas que não recebem do direito, por força de sua particular estrutura, o mesmo tratamento". ${ }^{28}$

Trata-se da divisão do direito de família pessoal e patrimonial. O plano dos direitos pessoais de família "é fortemente impregnado de princípios éticos, de tal modo que os próprios direitos lesados não se submetem aos mesmos cânones de outros ramos do direito, como, por exemplo, o das obrigações”. ${ }^{29}$ Já a regulamentação dos direitos patrimoniais de família está informada pelos princípios gerais do Código, assumindo, por vezes, a estrutura de uma obrigação e submetido, em outras, a regras que integram o direito das coisas. ${ }^{30}$

A divisão entre direitos pessoais e direitos patrimoniais de família acentuam a necessidade de partir de lógicas diferentes (poder-se-ia dizer: mentalidades diferentes) quando da apreciação e aplicação de institutos jurídicos que tocam uma e outra área.
Acentua-se, por assim dizer, a necessidade de desprendimento do Direito Civil patrimonializado do Código Civil de 1916 e acolhimento de um Direito Civil no qual a pessoa é valor-fonte, é o centro do ordenamento. ${ }^{31}$

Nesse quadro, a família que o Código Civil de 2002 regula e protege é a família democrática e igualitária, fortalecendo a personalidade (como individualidade) de cada pessoa que a compõe. O individualismo (como egoísmo) passa a ser uma ameaça à família, sinal de desorganização familiar passível de intervenção.

Assim, tendo em vista que as regras sobre deserdação demonstram evidente conteúdo patrimonial de pena, ela não atinge os "direitos de personalidade" 32 do deserdado; somente seus "direitos patrimoniais".

Mais um motivo para que se altere a forma de visualização e os efeitos dessa pena prevista em testamento.

Parece que a pena de deserdação (fundamento que infelizmente ain-

28 COUTO E SILVA, Clóvis do. Anteprojeto de Código Civil. Direito de Família. Exposição de motivos. Arquivos do Ministério da Justiça, n. 135, jul./set. 1975, p. 153.

29 Ibidem, p. 153.

30 Ibidem, p. 153.

31 Sobre a pessoa como valor-fonte, ver REALE, Miguel. Visão geral do projeto de Código Civil. Revista dos Tribunais, n. 752, p. 22-30, jun./1998. Ver também, do mesmo autor: $O$ espírito da nova lei civil e Os direitos da personalidade. Disponíveis em: $<$ http://www.miguelreale.com.br>. Acesso em 10 set. 2008.

32 Atualmente, com base no princípio fundamental da dignidade da pessoa (art. $1^{\circ}$, III, da Constituição Federal), considera como valor-fonte no Direito e a proteção dos direitos da personalidade (artigos 11 e 12, do Código Civil), pode-se afirmar que o Código 
da não é possível superar, em razão da regra legal estampada no Código) deve ser aplicada de acordo com a ideia de família que se propaga atualmente, bem como em vista da visualização da pessoa como valor-fonte de todo o Direito Privado.

O primeiro efeito dessa outra forma de aplicar a pena de deserdação é na discussão sobre o perdão. Outro tema importante é sobre os efeitos gerados pela deserdação.

Sobre esses assuntos, o item a seguir.

\section{B) A concretização do perdão e os efeitos da deserdação}

Para debater sobre os temas descritos no título acima, primeiro deve-se esclarecer que embora as leis pos- sam permitir que o ato deserdativo seja estabelecido em qualquer instrumento público, o Código Civil brasileiro ateve-se à tradicional solução da inserção em testamento (art. 1964, do Código Civil). ${ }^{33}$

No entanto, a pergunta a ser respondida é a seguinte: após a instituição da deserdação em testamento só haverá perdão com a revogação do testamento ou da cláusula testamentária que a instituiu?

A doutrina nacional dominante afirma que "a simples reconciliação do testador com o deserdado, por si só, não invalida a deserdação, uma vez que o testador não a revogue". ${ }^{34}$

No entanto, a Lei brasileira não prevê expressamente sobre o tema (diversamente do que faz para as questões da indignidade).

Civil possui um caráter muito mais humanista e social do que patrimonial, em que pese as questões patrimoniais sejam importantes numa sociedade capitalista na qual se vive. Na doutrina do jurista alemão Hans Hattenhauer, verifica-se a extensão da proteção da personalidade na seguinte passagem: "en sus conexiones, la personalidad, em continuo autoperfeccionamiento, adquiere determinados valores que se esfuerza por mantener, asumiendo en sí misma la imagen originaria del hombre, lo que confiere un valor y transcendência próprios y excludentes. Tanto el esfuerzo valorativo, como los valores adquiridos merecen una atención sin condiciones por parte de los demás hombres, así como protección contra posíbles perturbaciones y violaciones” (Conceptos Fundamentales del Derecho Civil. Introducción histórico-dogmática. Traducción de Gonzalo Hernández. Barcelona: Editora Ariel, 1987, p. 27).

33 PONTES DE MIRANDA. Tratado de direito privado. Parte Especial. Tomo LV. Direito das Sucessões: Sucessão em geral. Sucessão legítima. 3. ed. Rio de Janeiro: Borsoi, 1972, p. 295.

34 ITABAIANA DE OLIVEIRA. 1952, op. cit., p. 422. No mesmo sentido: VELOSO. 1993, op. cit., p. 451; HIRONAKA. 2007, op. cit., p. 303; CATEB. 2004, op. cit., p. 118, referindo que não se admite o perdão por conversas amistosas, prova testemunhal ou outros meios aleatórios permitidos no diploma processual. 
Considerando o que foi escrito antes sobre a autonomia do testador e a nova visão de família, parece mais próximo da realidade atual entendimento diverso: o testador, evidente, pode perdoar por revogação do testamento, mas também poderá perdoar por outros atos autênticos e também por meio de ações - fatos - com consequências jurídicas, inclusive pela reinserção do deserdado ao seu convívio familiar.

Pontes de Miranda já refletia sobre o tema. Entendia que o perdão era fato. Sendo fato, ele atuaria (a) como elemento de interpretação para se ajuizar da veracidade e da gravidade da injúria; (b) como indício contrário a outros indícios; (c) para a inovação da pressuposição ou da cláusula rebus sic stantibus; (d) como elemento complementar na prova do erro do testador. Assim, concluía que o testador poderia perdoar por ato autêntico ou testamento; fora disso, consistiria matéria de fato, porém de fato com consequências jurídicas. ${ }^{35}$

Parece que pensar dessa forma está de acordo com a visão não patri- monialista do Código Civil, pondo a pessoa (e suas relações) como fonte das relações, em especial das relações familiares.

Manter entendimento diverso enfatiza, ainda mais, o caráter patrimonial da deserdação, esvaziado pela nova concepção de Direito Privado que se quer desenvolver atualmente.

Já alertava Spencer Vanpré que "não há capítulo mais rebelde às inovações, mais aferrado ao passado, menos sensível ao oscilar da opinião"36 do que o Direito das Sucessões.

Portanto é dever do intérprete adaptar as regras ao sistema vigente, em especial dentro da visão do Código Civil de 2002 e seus princípios norteadores.

Já sobre os efeitos da deserdação, considerando que o Código Civil a trata como pena, como pena se deve raciocinar.

Dessa forma, no que tange à deserdação dos descendentes, os efeitos da deserdação não se estendem aos filhos do deserdado, que sucedem como se esse morto fosse (direito de representação). ${ }^{37}$

35 PONTES DE MIRANDA. Tratado de direito privado. Parte Especial. Tomo LVIII. Direito das Sucessões: Sucessão testamentária. Disposições testamentárias em geral, Formas ordinárias do testamento. 2. ed. Rio de Janeiro: Borsoi, 1969, p. 249-250.

36 VANPRÉ. s/d. op. cit., p. 126.

37 Importante mencionar que o direito de representação “dá-se na linha descendente, mas nunca na ascendente” (artigo 1.852 do Código Civil). 
Conforme resume Arnold Wald:

O princípio da personalidade da pena é um princípio que tem as suas raízes na própria Bíblia e que mereceu, atualmente, a consagração constitucional em todos os países civilizados. Efetivamente, já o Deuteronômio determinava, no seu cap. 24, 16, que os filhos não deveriam responder pelos pecados dos pais e que cada homem deveria responder pelos seus próprios pecados. ${ }^{38}$ Por sua vez, a Constituição Federal determina que "nenhuma pena passará da pessoa do acusado" (art. $5^{\circ}, \mathrm{XLV}$ ). Embora o texto constitucional tivesse em vista o Direito Penal, não há dúvida de que o princípio também se aplica na área do Direito das Sucessões. Assim sendo, a interpretação dominante na doutrina e jurisprudência tem, atualmente, um amparo constitucional. ${ }^{39}$

Nessa perspectiva, ao se reconhecer direito de representação aos filhos do herdeiro deserdado, um outro efeito há de existir.

É que considerando que os filhos do herdeiro deserdado sejam menores, pela regra insculpida no artigo 1.689 do Código Civil, os pais são usufrutuários e administradores de seus bens.

Como então imaginar a hipótese na qual um filho seja deserdado, ou seja, excluído dos bens que lhe caberiam na legítima, mas manter-lhe intactos os poderes de administração desses bens que agora são de seus filhos, netos do autor da herança e herdeiros por direito de representação?

Nessa linha de raciocínio, o herdeiro deserdado deve também ser privado do usufruto e da administração dos bens dos filhos menores, cabendo essa parcela do exercício do poder familiar ao outro genitor (que não era herdeiro), ou, se for o caso, a nomeação de um curador. ${ }^{40}$

No entanto, também sobre os efeitos da deserdação, os parâmetros descritos anteriormente (autonomia privada mitigada pelos princípios da eticidade e da socialidade) devem ser avaliados. Isso porque poderá ocorrer situações nas quais o único ou melhor

38 WALD, Arnoldo. Deserdação. Revista dos Tribunais, ano 70, v. 547, mai./1981, p. 15.

39 Idem. Há muito a jurisprudência tem o mesmo entendimento: BRASIL. Supremo Tribunal Federal. Recurso Extraordinário n. 16.845, $1^{\text {a }}$ Turma. Recorrente: M. B. L. F. Recorrido: P. B. L. Relator: Ministro Luis Gallotti. Brasília, 10 de julho de 1950. Acórdão disponível em: <http://www.stf.jus.br>. Acesso em 09 jul. 2009.

40 Esse efeito está previsto para os casos de exclusão por indignidade no parágrafo único do artigo 1.816 do Código Civil. 
administrador dos bens seja o então deserdado.

Como últimas palavras sobre o assunto, não se desconhece a regra que exige decisão judicial convalidando o ato de deserdação. No entanto, a decisão judicial, se não encontrar nos parâmetros adotados neste texto a forma de interpretação do ato de deserdação, será mero instrumento de legitimação da deserdação se obedecer a forma legal, qual seja, declaração em testamento, indicação da causa e estar a causa prevista em Lei.

O que se quer debater, neste texto, é o afastamento da deserdação ou de alguns de seus efeitos, em casos específicos nos quais a manutenção do ato do testador fere os princípios norteadores do sistema privado atual.

\section{CONSIDERAÇÕES FINAIS}

Como palavras finais, afirma-se que atualmente só é possível pensar sobre Direito Civil mediante a ideia de cultura, Direito como fenômeno da experiência jurídica.

\section{REFERÊNCIAS}

AMARAL, Francisco. A autonomia privada como princípio fundamental da ordem jurídica. Perspectivas estrutural e funcional. Boletim da
Assim, no Direito das Sucessões, mesmo com todas as limitações, não se abandona o valor da autonomia do testador, mas sempre mediante um controle sobre as ações dos particulares. Esse controle é exercido, em especial, pelos princípios norteadores na nova lei civil, mormente a equidade e a socialidade.

Num ambiente em que se protege a família como centro de direitos e deveres recíprocos entre seus componentes e destes para com a entidade familiar, a compreensão de instituto arraigado em concepção individualista e patrimonial como é o da deserdação deve ser o quanto mais próximo desses novos paradigmas.

Daí a alteração da compreensão da forma de perdão, para abarcar atitudes do testador que determinem o perdão, sem exigência de ato expresso. Além disso, no que for possível, impedir o alargamento dos efeitos da deserdação.

O texto tenta chamar o debate: a atual concepção de Direito Privado exige essa movimentação.

Faculdade de Direito de Coimbra. Número Especial. Estudos em homenagem ao Prof. Doutor Ferrer-Correia. Coimbra: Coimbra, 1989. 
AZEVEDO, Antônio Junqueira de.

O espírito de compromisso do direito das sucessões perante as exigências individualistas de autonomia da vontade e as supraindividualistas da família - herdeiro e legatário. Revista Brasileira de Direito de Família, n. 4, p. 56-63, jan./fev./mar. 2000. BUFFELAN-LANORE, Yvaine.

L'Autonomie de la Volonté em Matière D’Exhérédation. Revue Trimestrielle de Droit Civil, p. 456-480, LXIV, 1966.

BEVILÁQUA, Clóvis. Direito das Sucessões. Ed. José Luiz da Fonseca Magalhães, Salvador, 1899.

CAHALI, Francisco José; HIRONAKA, Giselda Maria Novaes. Direito das sucessões. 3. ed. São Paulo: Revista dos Tribunais, 2007.

CAPELO DE SOUSA, Rabindranath Valentino Aleixo. O direito geral de personalidade. Coimbra: Coimbra, 1995.

CARVALHO SANTOS, J. M. de. Código Civil Brasileiro de 1916 Interpretado. v. XXII. Rio de Janeiro: Freitas Bastos, 1937.

CATEB, Salomão de Araújo. Deserdação e indignidade no direito sucessório brasileiro. Belo Horizonte: Del Rey, 2004.

CARBONERA, Silvana Maria. O papel jurídico do afeto nas relações de família. In: FACHIN, Luiz Edson (Coord.). Repensando
Fundamentos do direito civil contemporâneo. Rio de Janeiro: Renovar, 1998.

COUTO E SILVA, Clóvis V. do. Anteprojeto de Código Civil. Direito de família. Exposição de motivos. Arquivos do Ministério da Justiça, n. 135, p. 153-192, jul./set. 1975.

FACHIN, Luiz Edson. Desafios e perspectivas do direito de família no Brasil contemporâneo. In: AZEVEDO, Antonio Junqueira de; TÔRRES, Heleno Taveira; CARBONE, Paolo (Coord.). Princípios do novo Código Civil brasileiro e outros temas. Homenagem a Tullio Ascarelli. São Paulo: Quartier Latin, 2008, p. 423-443.

FERRI, Luigi. La Autonomia Privada. Trad. y notas por Luis Sancho Mendizabal. Madrid: Revista de Derecho Privado, 1969.

HATTENHAUER, Hans. Conceptos Fundamentales del Derecho Civil. Introducción histórico-dogmática. Traducción de Gonzalo Hernández. Barcelona: Ariel, 1987.

ITABAIANA DE OLIVEIRA, Arthur Vasco. Tratado de direito das sucessões. São Paulo: Max Limonad, 1952.

GOMES, Orlando. Sucessões. Rio de Janeiro: Forense, 1998.

MARINHO, Josaphat. O direito e as contradições da lei e da vida. $R e$ vista de Informação Legislativa, 
ano 35, n. 138, Brasília, p. 49-54, abr./jun. 1998.

MAXIMILIANO, Carlos. Direito das sucessões. Rio de Janeiro: Freitas Bastos, 1964.

NORONHA, Carlos Silveira. Conceito e fundamentos de família e sua evolução na ordem jurídica. Revista Forense, v. 326, 1994.

PEREIRA, Caio Mário da Silva. Instituições de direito civil. v. 6. 11. ed. Rio de Janeiro: Forense, 1996.

PONTES DE MIRANDA. Tratado de direito privado. Parte especial. Tomo LV. Direito das sucessões: Sucessão em geral. Sucessão legítima. 3. ed. Rio de Janeiro: Borsoi, 1972.

- Tratado de direito privado. Parte especial. Tomo LVIII. Direito das ducessões: Sucessão testamentária. Disposições testamentárias em geral, formas ordinárias do testamento. 2. ed. Rio de Janeiro: Borsoi, 1969.

REALE, Miguel. $O$ direito como experiência: introdução à epistemologia jurídica. 2. ed. São Paulo: Saraiva, 2002.
. O espírito da nova Lei Civil. Disponível em: <http://www. miguelreale.com.br>. Acesso em: 10 set. 2008. . Os direitos da personalidade. Disponível em: <http://www. miguelreale.com.br>. Acesso em: 10 mar. 2008. . Um artigo-chave. Disponível em: <http://www.miguelreale.com. br>. Acesso em: 10 mar. 2008.

- Visão geral do projeto de Código Civil. Revista dos Tribunais, n. 752, p. 22-30, jun. 1998.

SCHLUTER, Wilfried. Código Civil Alemão - direito de família. Trad. da 9. ed. por Elisete Antoniuk. Porto Alegre: Fabris, 2002.

VAMPRÉ, Spencer. O que é o Código Civil. Conferências. São Paulo: Magalhães, s/d.

VELOSO, Zeno. Comentários ao novo Código Civil, v. 21. São Paulo: Saraiva, 2002. - Testamentos de acordo com a Constituição de 1988. 2 ed. Belém: CEJUP, 1993.

WALD, Arnold. Deserdação. Revista dos Tribunais, ano 70, v. 547, p. 11-15, mai. 1981. 